\title{
Assessment of nationally representative dietary studies in the Gulf Cooperation Council: A scoping review
}

\author{
Rukshana Hoque $^{1}$, Erin Strotheide ${ }^{2}$, Juliann Saquib ${ }^{3}$, Nazmus Saquib $^{\text {Corresp. } 3}$ \\ ${ }^{1}$ Diabetes \& Nutritional Sciences Division, King's College London, London, United Kingdom \\ 2 Research Unit, Sulaiman Al Rajhi University, Bukayriah, Al-Qassim, Saudi Arabia \\ ${ }^{3}$ College of Medicine, Sulaiman Al Rajhi University, Bukayriah, Al-Qassim, Saudi Arabia \\ Corresponding Author: Nazmus Saquib \\ Email address: a.saquib@sr.edu.sa
}

Background. Obesity is at a record high in Gulf Cooperation Council (GCC) countries and is expected to continue increasing. Diet is a major contributor to this disease, but there is inadequate nationally representative dietary research from these countries. The aim was to quantify the number dietary studies using food frequency questionnaires (FFQs) that have been conducted in individual GCC countries and to assess the quality of eligible studies.

Methodology. Four databases (PubMed, Web of Science, MEDLINE, and DOAJ) were searched for keywords; records were screened for eligible studies and data were abstracted on study characteristics (publication year, geographical locations, sample size, units of measurement, number of foods examined, number of Arab foods and key findings). Quality was assessed using an adapted Newcastle-Ottawa Quality Assessment Scale for cross-sectional studies.

Results. Only seven studies were eligible from four of six GCC countries (Saudi Arabia, Bahrain, Kuwait and Qatar). All eligible studies used FFQs, but only $29 \%$ used a validated questionnaire, one being in Arabic, and none of the studies used any additional tools to measure diet. Fifty-seven percent of studies made an effort to include local foods. The majority of studies (71\%) either measured frequency or quantity of food consumed, but only $29 \%$ attempted to account for both frequency and quantity.

Conclusions. The quality of studies varied and major weaknesses of FFQ validity and adaptability have been highlighted. More dietary investigations are needed using validated FFQs that have been adapted to the local GCC diets. Using reference tools will allow for better dietary estimations. 


\section{Assessment of nationally representative dietary}

3 studies in the Gulf Cooperation Council: A scoping

\section{4 review}

5

6

7 Rukshana Hoque ${ }^{1}$, Erin Strotheide ${ }^{2}$, Juliann Saquib ${ }^{3}$, Nazmus Saquib ${ }^{3}$

8

$9 \quad{ }^{1}$ Diabetes \& Nutritional Sciences Division, King's College London, London, United Kingdom

$10 \quad{ }^{2}$ Research Unit, Sulaiman Al Rajhi University, Bukayriah, Al-Qassim, Saudi Arabia

$11{ }^{3}$ College of Medicine, Sulaiman Al Rajhi University, Bukayriah, Al-Qassim, Saudi Arabia 12

13 Corresponding Author:

14 Nazmus Saquib ${ }^{3}$

15 PO Box 777, Bukayriah, Al-Qassim, 51941, Saudi Arabia

16 Email address: a.saquib@sr.edu.sa 


\section{Abstract}

18 Background. Obesity is at a record high in Gulf Cooperation Council (GCC) countries and is expected to continue increasing. Diet is a major contributor to this disease, but there is inadequate nationally representative dietary research from these countries. The aim was to quantify the number dietary studies using food frequency questionnaires (FFQs) that have been conducted in individual GCC countries and to assess the quality of eligible studies.

Methodology. Four databases (PubMed, Web of Science, MEDLINE, and DOAJ) were searched for keywords; records were screened for eligible studies and data were abstracted on study characteristics (publication year, geographical locations, sample size, units of measurement, number of foods examined, number of Arab foods and key findings). Quality was assessed using an adapted Newcastle-Ottawa Quality Assessment Scale for cross-sectional studies.

Results. Only seven studies were eligible from four of six GCC countries (Saudi Arabia, Bahrain, Kuwait and Qatar). All eligible studies used FFQs, but only 29\% used a validated questionnaire, one being in Arabic, and none of the studies used any additional tools to measure diet. Fifty-seven percent of studies made an effort to include local foods. The majority of studies (71\%) either measured frequency or quantity of food consumed, but only $29 \%$ attempted to account for both frequency and quantity.

Conclusions. The quality of studies varied and major weaknesses of FFQ validity and

\section{Introduction}

Obesity is an epidemic in the countries of the Gulf Cooperation Council (GCC) (that is, Saudi adaptability have been highlighted. More dietary investigations are needed using validated FFQs that have been adapted to the local GCC diets. Using reference tools will allow for better dietary estimations. Arabia, Bahrain, Kuwait, Oman, Qatar, and United Arab Emirates). Approximately one out of every three adults is obese (Body Mass Index $\geq 30$ ), and the obesity prevalence has been rising in every member country. For example, between 2011 and 2016, the obesity prevalence rose in Saudi Arabia (KSA) from 32.1 to $35.4 \%$, in Bahrain from $27.1 \%$ to $29.8 \%$, in Kuwait from $35.1 \%$ to $37.9 \%$, in Oman from $23.7 \%$ to $27 \%$, in Qatar from $31.8 \%$ to $35.1 \%$, and in the United Arab Emirates (UAE) from $28.3 \%$ to $31.7 \%$ (1). Apart from obesity, the GCC countries are also leading countries in the world in diabetes and cardiovascular disease prevalence (2-4).

There is mounting evidence of a potential causal link between specific dietary factors (such as, fruit, vegetable, processed meat, and trans-fat intake) and the above mentioned chronic conditions (5-7). A recent systematic review of dietary data from 195 countries found that $22 \%$ of all adult deaths worldwide are due to unhealthy diet; more than half of diet-related deaths are attributable to a high sodium intake, low intake of whole grains, and low fruit intake (8).

Several factors likely contribute to obesity in GCC countries. With increased wealth from oil reserves, these countries have seen rapid economic growth. The urbanization of the landscape has seen a rise in international fast food chains, making it easier and quicker to consume 
57 processed foods $(9,10)$. This has resulted in a change of diet from traditional, locally produced
58 goods such as wheat, vegetables and dates to fast foods high in fat, sugar and salt content (11).

58

59

60

61

62

63

64

65

66

67

68

69

70

71

72

73

74

75

76

77

78

79

80

81

82

83

84

85

86

87

88

89

90

91

92

93

94

95

96 Whist all GCC countries have attempted to develop a national plan that addresses nutrition and physical activity, most have not followed up, which makes it difficult to evaluate the impact of such programs (12). Changes in lifestyle such as increased use of cars, electrical home appliances, television and gaming devices have resulted in a more sedentary lifestyle $(9,13)$. The extremely hot climate found in these countries is also likely to deter outdoor activities with people opting to use cars, even for short journeys $(9,14)$. A combination of all these is likely to play a role in the current epidemic.

Given the high prevalence of chronic conditions in the GCC, one would expect that these countries engage extensively in diet and nutrition research. However, dietary studies have been limited; only approximately $1 \%$ of global dietary research has come from Arab countries (15). Their $h$-indices [measurement of performance by combining productivity (number of papers) and impact (number of citations)] are much lower than neighbouring non-Arab countries (16).

One would similarly expect that assessment tools used in dietary studies from GCC countries would differ from those in European or North American studies as Middle Eastern diets vary a great deal from their western counterparts. For example, date palm fruit is highly consumed in Gulf regions, with daily consumption ranging from 68 - $164 \mathrm{~g}$ daily (17-19), whereas only $140 \mathrm{~g}$ of this fruit is consumed annually in Europe (20). Differences such as these should be accommodated for when designing dietary assessment tools.

The usual assessment tools used in dietary research are 24-hour dietary recall (openended, food consumed the previous day, conducted by trained interviewer), diet records (openended, participants trained to record own diet), and food frequency questionnaires (FFQs) (closed-ended, typically a food list and frequency of consumption in a given period). All have strength and limitations (21), but due to low cost, low respondent burden and ease of use compared to other methods, FFQs are thought to be the best choice for measuring habitual diet in large populations. The usefulness and reliability of FFQs have been demonstrated with strong correlations with diet records $(22,23)$, dietary recalls $(24-26)$, and objective biomarkers of diet $(24,25)$. As an FFQ is a self-reported subjective tool, FFQs should be tested for validity alongside a reference tool.

The authors' aimed to conduct both a quantitative and qualitative review of all dietary studies conducted within each GCC country. To be as nationally representative as possible and to provide a current and more reflective picture of diet in the GCC, only studies carried out in multiple regions (must be a minimum of two regions) were included. Dietary research that used FFQs in individual GCC countries (Bahrain, Kuwait, Oman, Qatar, KSA, UAE) over the past ten years (2009-2019) were assessed. The characteristics of the studies were described and their quality was assessed using a widely accepted scoring tool $(27,28)$. The objectives were to (1) identify multi-regional GCC dietary studies that used FFQs, (2) assess the quality of the studies, and (3) offer recommendations for future dietary assessments.

PeerJ reviewing PDF | (2020:06:49675:1:1:NEW 19 Aug 2020) 
97

98

99

100

101

102

103

104

105

106

107

108

109

110

111

112

113

114

115

116

117

118

119

120

121

122

123

124

125

126

127

128

129

130

131

132

133

134

135

136

\section{Method}

\section{SEARCH STRATEGY AND INCLUSION CRITERIA}

This review was conducted in May 2019. PubMed, Web of Science, MEDLINE, and Directory of Open Access Journals (DOAJ) databases were searched using the following terms: "diet," "frequency questionnaire" in combination with each of the Gulf Cooperation Council countries ("Bahrain", "Kuwait", “Oman", "Qatar", "Saudi Arabia”, "UAE”). A total of 431 records were identified from PubMed $(n=241)$,Web of Science $(n=34)$, MEDLINE $(n=132)$ and DOAJ $(n=$ $24)$. Duplicates $(n=39)$ were removed, and the unique records $(n=392)$ were screened for the following inclusion criteria: (1) assessed diet using a food frequency questionnaire, (2) included data from multiple regions/cities (minimum two) of the Gulf country of focus, and (3) data were collected in the last ten years (that is, 2009 and later).

\section{EXCLUSION OF STUDIES}

Studies were excluded if they (1) examined data from only one specific region/city/population group and therefore were not necessarily nationally representative, (2) were multi-national studies that did not give Gulf-nation-specific results, (3) were not conducted in a GCC country, (4) were intervention studies where the diet had purposefully been changed, (5) were review or meta-analysis papers, (6) used an assessment tool other than a food frequency questionnaire, or (7) had no findings related to diet or did not report those findings. Therefore, the final analysis was limited to seven dietary studies (Fig. 1).

\section{DATA CHARTING PROCESS}

After an initial search and screening, the following data from each study were charted:

publication year, author(s) name(s), geographical location, sample size, age range of participants, dietary assessment tool(s) used, units of measurement (for example, times/week, servings/day, etc.), total number of foods examined, number of Arab-specific foods (and where possible, the type and name of food), whether the questionnaire was validated, and dietary findings related to the most common foods studied. Any discrepancy was resolved through discussion and consensus among the authors.

\section{CRITICAL APPRAISAL OF STUDIES}

Using a scoring system adapted from Newcastle-Ottawa Quality Assessment Scale for crosssectional studies (27), each study was scored for (1) representativeness of the sample, (2) sample size, (3) non-respondents, (4) ascertainment of the exposure, (5) adaptability, (6) assessment of the outcome, and (7) statistical test (Appendix 1).

\section{DATA ANALYSIS}

Study characteristics, along with main findings related to dietary intake/habits were tabulated. Additionally, indicators of study quality were assigned point values based on the quality 
137

138

139

140

141

142

143

144

145

146

147

148

149

150

151

152

153

154

155

156

157

158

159

160

161

162

163

164

165

166

167

168

169

170

171

172

173

174

assessment scoring scale and then summed. Each study was categorized as excellent (9-12 points), satisfactory (5-8 points), or unsatisfactory (0-4 points).

\section{Results}

\section{STUDY CHARACTERISTICS}

The search resulted in seven studies published between 2009 and 2019. Tables 1 and 2 show three studies were conducted in Saudi Arabia, one in Kuwait, one in Bahrain, and two in Qatar; there were no studies from Oman or the UAE. A majority of the studies $(n=6)$ had sample sizes greater than 1000 participants, and all studies included a sample size justification. Almost all studies had a 1:1 male: female ratio (range 1: 0.9-1.4 male: female). Fifty-seven percent $(n=4)$ of the studies were carried out with adolescents (12-19 years of age), whereas $33 \%(n=2)$ included both adolescents and adults. One study (14\%) classified participants 18 years and older as adults, thus the study was considered to be carried out on an all-adult population (29).

All studies used FFQs, but three administered the FFQ through face-to-face interviews; the rest were self-administered. One study (30) used pictures to deduce serving sizes.

The number of food items assessed ranged from two (non-specified fruits and vegetables) (31) to twenty items (29). Only two of seven studies used validated questionnaires, adapted it for local cuisine, and had it pilot tested for suitability $(29,32)$ and from these, only one was conducted in Arabic; the other five studies did not use validated FFQs.

Key findings from each study varied based on the units of measurement. Frequency ranged from days per week, times per day, servings per day, to categories (such as, always, sometimes, never). Quantity options were servings per day, serving sizes, and serving sizes via selection of pictures.

\section{QUALITY ASSESSMENT OF STUDIES}

Only one of all included studies used a validated Arabic questionnaire (all were presented in English in the article) and none used any additional tools to measure diet. Donnelly et al. (29) translated the questionnaire to Arabic and back to English to ensure correct language usage. For relevance to local contexts, focus groups were conducted and the questionnaire pilot tested and thereafter further refined. Musaiger et al. (32) modified a previously validated questionnaire (Family Eating and Activity Habits Questionnaire) (33) and adapted it to ensure it reflected dietary habits of the target population. Contents of the FFQ were validated by experts in the field of nutrition, public health, and epidemiology and the questionnaire underwent pilot and test-retesting (32).

Table 3 shows $57 \%(\mathrm{n}=4)$ of the studies made an effort to include local foods, scoring a point for adaptability, whereas the other three studies either did not incorporate any local foods or did not mention it in their studies. 
175

176

177

178

179

180

181

182

183

184

185

186

187

188

189

190

191

192

193

194

195

196

197

198

199

200

201

202

203

204

205

206

207

208

209

210

211

212

213

Five studies measured either frequency or quantity, whilst two studies scored the maximum three points for 'assessment of outcome' by having units of measurement that took into account both frequency and quantity (that is, times/week and servings/day).

All studies used appropriate statistical analysis and $86 \%(n=6)$ had an adequate response rate $(\geq 60 \%)$. One study had $52.1 \%$ response rate (29) and one study did not compare between respondent and non-respondent characteristics or take non-responses into account (or did not mention it in their study) (34).

\section{Discussion}

With such a high prevalence of diseases to which diet is a major contributor, it is surprising that there are so few multi-regional studies that investigated diet in the GCC in the past ten years. Five out of the seven studies included in this review did not use validated FFQs.

Dietary summaries show intake of fruit and vegetables being far below the recommended three servings of vegetables and two servings of fruit per day (35). In Saudi Arabia, only 5.2\% of individuals met the recommendation for fruit intake and $7.5 \%$ for vegetable intake. In contrast, consumption of sugary beverages was oversubscribed, with an average of $36 \%$ of adolescents (14-19 years old) reporting daily consumption (34) and 27\% of 15-60 year olds (30), exceeding local and global recommendations of sugary-drink consumption (36-38). This low fruit and vegetable intake, combined with high sugary-beverage consumption, suggests a poor-quality diet across the GCC.

The varying methods of measuring diet made it difficult to compare consumption. For example, $57 \%$ of the studies assessed diet using frequency questions (how often), whilst $43 \%$ measured frequency and quantity (portions or serving size). At times, the response categories were too broad for in-depth analysis. For example, "Do you regularly consume meals? Yes/No" (32) does not specify which meals, how many meals, or the content of the meals. Similarly, "How often do you drink a glass of milk?" (39) does not quantify the size of the glass or the amount of milk consumed.

Adaptability was one of the main issues relating to study quality according to the quality assessment scoring scale. Studies need to make it explicit how they have categorized foods, for example, whether they have classified potatoes as starch, tuber, snack, fast food, etc. Four studies attempted to include local foods, with a maximum of two or three items added (and mentioned in the article) $(29,30,38,40)$. It is concerning that the other three studies did not mention any native foods at all. In Tabacchi's review (41), it is suggested that an FFQ with less than 70 food items reduces the quality of nutritional information that can be deduced. None of the studies included in this review had 70 items; the most was 20, the average being 11 items. Nutritional status and dietary patterns differ over time and from region to region; without the incorporation of local foods and without categorizing them under more common food groups, it is entirely possible to mask important epidemiological links between diet and disease.

Peer] reviewing PDF | (2020:06:49675:1:1:NEW 19 Aug 2020) 
214

215

216

217

218

219

220

221

222

223

224

225

226

227

228

229

230

231

232

233

234

235

236

237

238

239

240

241

242

243

244

245

246

247

248

249

250

251

252

253

An overall poor validity of FFQs was found in this review. Only one study used a validated Arabic FFQ and scored three points out of a possible four points on the quality assessment scale. Validation in large-scale studies is especially important as FFQs are prone to measurement errors and come with inherent self-bias. FFQs rely on an individual's memory and his/her own perception of food sizes, thus under-reporting remains a common problem (42-45). Researchers have made extensive efforts in the last two decades to mitigate some of the errors with self-reporting data (46-48), but diet and eating patterns are complex, and FFQs are still thought to have clear value and insight that solely objective measures cannot provide $(49,50)$. One of the ways to minimize errors is to use a validated FFQ. FFQs are not one-size-fits-all, and it is integral that questionnaires be adapted/modified to suit the population with which they are being used. This includes first developing a good FFQ to standard procedure (51), FFQs being in the native language, which for GCC is predominantly Arabic, and including as many local foods as possible.

Within obesity research, two areas are deficient: understanding the role of dietary habits in the obesity epidemic and sufficient intervention studies on weight loss via dietary change. Research on dietary habits in the obesity epidemic may be lacking due to a shortage of skilled researchers and research centers (12). Obtaining accurate dietary data requires specialized nutritionists/dieticians and controlled research settings, but this is a problem across many Gulf states, where it is difficult to have sufficient numbers of well-trained staff to serve large populations and areas like Saudi Arabia (Table 1). Investments should be made in specialized university health education and research courses and training in hospital departments; this will take time and resources but is a necessary step to produce expert personnel that can adequately face the challenges of regional obesity research (12).

Research in this field may also be looking at risk factors found in Western countries and not necessarily exploring factors that are unique to the socio-cultural environment of the GCC. For example, women have been shown to be less active than men across Gulf countries $(52,53)$ and more sedentary than their British counterparts $(54,55)$, but reasons for this behavior was poorly understood. Only by exploring the socioeconomic, environmental and cultural contexts further was it understood that the greatest barrier to physical activity for women was a lack of facilities rather than assumed low levels of knowledge, dress codes (56) or high obese-body acceptance (57). Samara et al. suggested that future health strategies should focus on providing culturally sensitive exercise facilities for women (56). A similar approach needs to be taken for nutrition and diet, where interventions, based on survey results, acknowledge and work with, not against, local culture and social norms (58). Such intervention studies need to have tangible goals, clear action plans and sufficient follow-up to evaluate long-term effectiveness (59).

Limitations of this review are that the search was carried out on four main databases; this may have missed studies published in other journals not found within these databases, and those that are currently underway or not yet published. However, additional cross-checking was performed with reference lists to ensure the maximum number of studies were screened. The small number of studies limited the generalizability of findings. To the authors' knowledge, there 
254

255

256

257

258

259

260

261

262

263

264

265

266

267

268

269

270

271

272

273

274

275

276

277

278

279

280

281

282

283

284

285

286

287

288

289

290

291

292

293

are no other reviews similar to the current study. There are studies that have looked at other methods for country-specific dietary assessment (49) and the Newcastle-Ottawa Assessment Scale, which was adapted for this study, has been used to assess study quality but not in the same context as the current study $(27,60)$. Finally, although studies have looked at dietary research from other parts of the world, no study has quantified the number of dietary studies coming specifically from the GCC and assessed their quality. Our review is unique in these ways, so the results of this present study cannot be easily compared to other studies.

A particular strength is the quality assessment aspect of this review. Adapting a scoring system allowed for objective assessment of studies. It highlighted that most of the included studies were either satisfactory $(n=4)$ or excellent $(n=3)$, whilst making it clear that the greatest weaknesses were in the number of food items and the validity and adaptability of FFQs, which researchers should take into consideration when designing future studies. Another strength is that the review focused on large-scale, multi-regional studies, which are more representative of the respective GCC nations' populations.

\section{RECOMMENDATIONS}

As validity and adaptability were the lowest scoring categories, it is important to address this.

1. Validation can be assured by using a reference method. There are a variety of other methods used to measure diet, including self-reporting food records and 24-hour dietary recall (24-HDRs), but the most objective reference tool is food or nutrient biomarkers $(21,61)$. In theory, biomarkers look like a promising method to remove the human error that comes with self-reported dietary data, but their widespread use is hindered because there are only a few known and validated biomarkers. One of the well-known biomarkers could be used as a reference measurement to validate FFQs and to assess their accuracy.

2. As KSA is the largest of the GCC countries, a quality assessment of all FFQs used in KSA should be undertaken. Comparisons should be made to see how similar they are, how inclusive they are of local cuisine and if the questionnaires are validated. This will be a labour-intensive task as the questionnaires are rarely attached to the articles or submitted as supplementary material; thus, authors will need to be contacted for original FFQs. This will give an overview of the versions of FFQs available and the Arabic food items included. By noting what foods are not represented in these questionnaires, additional foods can be added and attempts made to validate the FFQ. A recent FFQ developed by Gosadi et al. (2017) is a promising start for KSA (62). The Arabic FFQ had 140 food items and ensured it had a comprehensive food list by comparing it with open-ended information from 24-hour dietary recalls to find that $85 \%$ of food items recalled were covered in the FFQ. The FFQ has been piloted and its reliability assessed (Cronbach's alpha test and test-retest) and it should now be used in other regions. This standard of FFQ development should be carried out with other GCC countries as well to better capture dietary habits. 
294

295

296

297

298

299

300

301

302

303

304

305

306

307

308

309

310

311

312

313

314

315

316

\section{7}

318

319

320

321

322

323

324

325

326

327

328

329

330

331

332

333

334

335
3. The review only included cross-sectional studies because they give a current picture of diet (observations of diet at a given point in time). Carrying out a longitudinal study analysis (repeated observations of a population over time) would illuminate how diet has changed over time to make better-informed future predictions.

\section{Conclusions}

This is the first review to collect, quantify and critique the quality of data from dietary studies conducted in GCC countries by using an objective scoring system approach. Study quality varied, and major weaknesses of FFQ validity and adaptability have been highlighted.

Findings consistently showed that the majority of GCC populations are not meeting the recommended fruit and vegetable intake, and sugary-beverage consumption is on the rise, implying a poor diet. However, interpretations are made with caution due to the low study sample included $(n=7)$. In these GCC countries, where obesity levels are steadily rising, more dietary investigations are necessary. The use of validated FFQs in conjunction with other instruments like biomarkers, 24-hour recalls and/or food records is likely to provide more accurate dietary estimations.

In conclusion, it is essential that researchers develop well-designed, validated FFQs that are adapted for the GCC to standardise dietary assessments across studies.

\section{References}

1. Global health observatory. Prevalence of obesity among adults - Estimates by country. Geneva: World Health Organization; 2017 (http://apps.who.int/gho/data/node.main.A900A?lang=en, accessed 29 May 2019).

2. M Alqarni SS. A review of prevalence of obesity in Saudi Arabia. J Obes Eat Disord. 2016; 02(02).

3. Alqurashi KA, Aljabri KS, Bokhari SA. Prevalence of diabetes mellitus in a Saudi community. Ann Saudi Med. 2011; 31(1):19-23.

4. Aljefree N, Ahmed F. Prevalence of cardiovascular disease and associated risk factors among adult population in the Gulf Region: A systematic review. Adv Public Heal. 2015; 2015:1-23.

5. Micha R, Shulkin ML, Peñalvo JL, Khatibzadeh S, Singh GM, Rao M, Fahimi S, Powles J, Mozaffarian D. Etiologic effects and optimal intakes of foods and nutrients for risk of cardiovascular diseases and diabetes: Systematic reviews and meta-analyses from the Nutrition and Chronic Diseases Expert Group (NutriCoDE). Kiechl S, editor. PLoS One. 2017;12(4):e0175149.

6. Diet, nutrition, physical activity and cancer: A global perspective. London: World Cancer Research Fund; 2018 (https://www.wcrf.org/dietandcancer, accessed 26 September 2019).

7. WCRF/AICR systematic literature review continuous update project report: The 
associations between food, nutrition and physical activity and the risk of colorectal cancer. London: World Cancer Research Fund, American Institute for Cancer Research ICL; 2010 (https://www.wcrf.org/sites/default/files/SLR_colorectal_cancer_2010.pdf, accessed 21 September 2019).

8. GBD 2017 Diet Collaborators. Health effects of dietary risks in 195 countries, 1990-2017: A systematic analysis for the Global Burden of Disease Study 2017. Lancet. 2019; 393(10184):1958-72.

9. Alnohair S. Obesity in Gulf countries. Int J Health Sci (Qassim). 2014; 8(1):79-83.

10. Al-Mahroos F, Al-Roomi K. Overweight and obesity in the Arabian Peninsula: An overview. J R Soc Promot Health. 1999;119(4):251-3.

11. Al-Othaimeen AI, Al-Nozha M, Osman AK. Obesity: An emerging problem in Saudi Arabia. Analysis of data from the National Nutrition Survey. East Mediterr Heal J. 2007;13(2):441-8.

12. Samara A, Andersen PT, Aro AR. Health promotion and obesity in the Arab Gulf States: Challenges and good practices. J Obes. 2019: 4756260.

13. Musaiger AO. Overweight and obesity in the Eastern Mediterranean Region: Can we control it? East Mediterr Health J. 2004; 10(6):789-793.

14. Al-Kandari YY. Prevalence of obesity in Kuwait and its relation to sociocultural variables. Obes Rev. 2006; 7(2):147-54.

15. Sweileh WM, Al-Jabi SW, Sawalha AF, Zyoud SH. Bibliometric analysis of nutrition and dietetics research activity in Arab countries using ISI Web of Science database.

Springerplus. 2014; 3(1):718.

16. Hirsch JE. An index to quantify an individual's scientific research output. Proc Natl Acad Sci U S A. 2005; 102(46):16569-72.

17. Al-Mssalle MQ. Consumption of dates among Saudi Adults and its association with the prevalence of type 2 diabetes. Asian J Clin Nutr. 2018; 10(2):58-64.

18. Ismail B, Henry J, Haffar I, Baalbaki R. Date consumption and dietary significance in the United Arab Emirates. J Sci Food Agric. 2006; 86(8):1196-201.

19. Aleid SM, Al-Khayri JM, Al-Bahrany AM. Date palm status and perspective in Saudi Arabia. In: Date palm genetic resources and utilization. Dordrecht: Springer Netherlands. 2015:49-95.

20. Ordines B. Study of the main European markets for dates and of the commercial potential of non-traditional varieties. Food and Agriculture Organization of the United Nations; 2000 (http://www.fao.org/3/a-y2745e.pdf, accessed 24 April 2019).

21. Shim JS, Oh K, Kim HC. Dietary assessment methods in epidemiologic studies. Epidemiol Health. 2014:e2014009.

22. Rimm EB, Giovannucci EL, Stampfer MJ, Colditz GA, Litin LB, Willett WC. Reproducibility and validity of an expanded self-administered semiquantitative food frequency questionnaire among male health professionals. Am J Epidemiol. 1992; 135(10):1114-26.

23. Willett WC, Sampson L, Stampfer MJ, Rosner B, Bain C, Witschi J, Hennekens $\mathrm{CH}$, Speizer FE. Reproducibility and validity of a semiquantitative food frequency questionnaire. Am J Epidemiol. 1985; 122(1):51-65.

24. Katsouyanni K. Reproducibility and relative validity of an extensive semi-quantitative food frequency questionnaire using dietary records and biochemical markers among Greek schoolteachers. Int J Epidemiol. 1997; 26(90001):118S - 127. 
382

383

384

385

386

387

388

389

390

391

392

393

394

395

396

397

398

399

400

401

402

403

404

405

406

407

408

409

410

411

412

413

414

415

416

417

418

419

420

421

422

423

424

425

426

427

25. Brunner E, stallone D, Juneja M, bingham S, Marmot M. Dietary assessment in Whitehall II: Comparison of $7 \mathrm{~d}$ diet diary and food-frequency questionnaire and validity against biomarkers. Br J Nutr. 2001; 86(3):405-14.

26. Marques-Vidal P, Ross A, Wynn E, Rezzi S, Paccaud F, Decarli B. Reproducibility and relative validity of a food-frequency questionnaire for French-speaking Swiss adults. Food Nutr Res. 2011; 55.

27. Herzog R, Álvarez-Pasquin MJ, Díaz C, Del Barrio JL, Estrada JM, Gil Á. Are healthcare workers' intentions to vaccinate related to their knowledge, beliefs and attitudes? A systematic review. BMC Public Health. 2013; 13:154.

28. Stang A. Critical evaluation of the Newcastle-Ottawa scale for the assessment of the quality of nonrandomized studies in meta-analyses. Eur J Epidemiol. 2010; 25(9):603-5.

29. Donnelly TT, Fung TS, Al-Thani A-AbM. Fostering active living and healthy eating through understanding physical activity and dietary behaviours of Arabic-speaking adults: A cross-sectional study from the Middle East. BMJ Open. 2018; 8(4):e019980.

30. Moradi-Lakeh M, El Bcheraoui C, Afshin A, Daoud F, AlMazroa MA, Al Saeedi M, Basulaiman M, Memish ZA, Al Rabeeah AA, Mokdad AH. Diet in Saudi Arabia: Findings from a nationally representative survey. Public Health Nutr. 2017; 20(06):107581.

31. Haj Bakri A, Al-Thani A. Disease Risk factor surveillance: Qatar STEPS Report 2012. Geneva: World Health Organization; 2012 (http:/www.who.int/chp/steps/qatar/en/, accessed 2 April 2019).

32. Musaiger A, Bader Z, Al-Roomi K, D'Souza R. Dietary and lifestyle habits amongst adolescents in Bahrain. Food Nutr Res. 2011; 55(1):7122.

33. Golan M, Weizman A. Reliability and validity of the Family Eating and Activity Habits Questionnaire. Eur J Clin Nutr. 1998; 52(10):771-7.

34. Al-Hazzaa HM, Abahussain NA, Al-Sobayel HI, Qahwaji DM, Musaiger AO. Physical activity, sedentary behaviors and dietary habits among Saudi adolescents relative to age, gender and region. Int J Behav Nutr Phys Act. 2011; 8:140.

35. Saudi dietary guideline (Healthy diet palm). Riyadh: Ministry of Health Publications; 2012 (https://www.moh.gov.sa/en/Ministry/MediaCenter/Publications/Documents/final english إنجليزي العلمي الكتاب.pdf, accessed 2 April 2019).

36. Eaton DK, Kann L, Kinchen S, Shanklin S, Flint KH, Hawkins J, Harris WA, Lowry R, McManus T, Chyen D, Whittle L, Lim C, Wechsler H, Centers for Disease Control and Prevention (CDC). Youth risk behavior surveillance - United States, 2011. MMWR Surveill Summ. 2012; 61(4):1-162.

37. Al Qaseer B, Batarseh S, Asa'ad A. Global school-based student health survey - Jordan. Geneva: World Health Organization; 2007.

38. AlBuhairan FS, Tamim H, Al Dubayee M, AlDhukair S, Al Shehri S, Tamimi W, El Bcheraoui C, Magzoub ME, de Vries N, Al Alwan I. Time for an adolescent health surveillance system in Saudi Arabia: Findings from "Jeeluna." J Adolesc Health. 2015; 57(3):263-9.

39. Alsheridah N, Akhtar S. Diet, obesity and colorectal carcinoma risk: Results from a national cancer registry-based middle-eastern study. BMC Cancer. 2018; 18(1):1227.

40. Al Baho A, Badr HE. Global school-based health survey - Kuwait. Geneva: World Health Organization; 2011

(https://www.who.int/ncds/surveillance/gshs/GSHS_Kuwait_report_2011.pdf, accessed

Peer] reviewing PDF | (2020:06:49675:1:1:NEW 19 Aug 2020) 
428

429

430

431

432

433

434

435

436

437

438

439

440

441

442

443

444

445

446

447

448

449

450

451

452

453

454

455

456

457

458

459

460

461

462

463

464

465

466

467

468

469

470

471

472

473

on 2 April 2019).

41. Tabacchi G, Amodio E, Di Pasquale M, Bianco A, Jemni M, Mammina C. Validation and reproducibility of dietary assessment methods in adolescents: A systematic literature review. Public Health Nutr. 2014; 17(12):2700-14.

42. Subar AF, Kipnis V, Troiano RP, Midthune D, Schoeller DA, Bingham S, Sharbaugh CO, Trabulsi J, Runswick S, Ballard-Barbash R, Sunshine J, Schatzkin A. Using intake biomarkers to evaluate the extent of dietary misreporting in a large sample of adults: The OPEN Study. Am J Epidemiol. 2003; 158:1-13.

43. Beaton GH, Milner J, Corey P, McGuire V, Cousins M, Stewart E, de Ramos M, Hewitt D, Grambsch PV, Kassim N, Little JA. Sources of variance in 24-hour dietary recall data: implications for nutrition study design and interpretation. Am J Clin Nutr. 1979; 32(12):2546-59.

44. Freudenheim JL, Marshall JR. The problem of profound mismeasurement and the power of epidemiological studies of diet and cancer. Nutr Cancer. 1988; 11(4):243-50.

45. Kipnis V, Subar AF, Midthune D, Freedman LS, Ballard-Barbash R, Troiano RP, Bingham S, Schoeller DA, Schatzkin A, Carroll RJ. Structure of dietary measurement error: Results of the OPEN biomarker study. Am J Epidemiol. 2003; 158:14-21.

46. Freedman LS, Commins JM, Moler JE, Arab L, Baer DJ, Kipnis V, Midthune D, Moshfegh AJ, Neuhouser ML, Prentice RL, Schatzkin A, Spiegelman D, Subar AF, Tinker LF, Willett W. Pooled results from 5 validation studies of dietary self-report instruments using recovery biomarkers for energy and protein intake. Am J Epidemiol. 2014; 180(2):172-88.

47. Freedman LS, Kipnis V, Schatzkin A, Tasevska N, Potischman N. Can we use biomarkers in combination with self-reports to strengthen the analysis of nutritional epidemiologic studies? Epidemiol Perspect Innov. 2010; 7(1):2.

48. Kipnis V, Midthune D, Freedman L, Bingham S, Day NE, Riboli E, Ferrari P, Carroll RJ. Bias in dietary-report instruments and its implications for nutritional epidemiology. Public Health Nutr. 2002; 5(6A):915-23.

49. Kirkpatrick SI, Vanderlee L, Raffoul A, Stapleton J, Csizmadi I, Boucher BA, Massarelli I, Rondeau I, Robson PJ. Self-report dietary assessment tools used in Canadian research: A scoping review. Adv Nutr. 2017; 8(2):276-89.

50. Subar AF, Freedman LS, Tooze JA, Kirkpatrick SI, Boushey C, Neuhouser ML, Thompson FE, Potischman N, Guenther PM, Tarasuk V, Reedy J, Krebs-Smith SM. Addressing current criticism regarding the value of self-report dietary data. J Nutr. 2015; 145(12):2639-45.

51. Willett W. Nutritional epidemiology. Oxford: Oxford University Press; 2012 (http://www.oxfordscholarship.com/view/10.1093/acprof:oso/9780199754038.001.0001/a cprof-9780199754038, accessed 9 April 2019).

52. Al-Nozha MM, Al-Hazzaa HM, Arafah MR, Al-Khadra A, Al-Mazrou YY, Al-Maatouq MA, Khan NB, Al-Marzouki K, Al-Harthi SS, Abdullah M, Al-Shahid MS. Prevalence of physical activity and inactivity among Saudis aged $30-70$ years. A population-based crosssectional study. Saudi Med J. 2007; 28(4):559-68.

53. Mabry RM, Reeves MM, Eakin EG, Owen N. Evidence of physical activity participation among men and women in the countries of the Gulf Cooperation Council: A review. Obes Rev. 2009; 11(6):457-64.

54. Al-Hazzaa HM, Al-Nakeeb Y, Duncan MJ, Al-Sobayel HI, Abahussain NA, Musaiger 
474

475

476

477

478

479

480

481

482

483

484

485

486

487

488

489

490

491

492

493

494

495

496

497

498

499

500

501

502

503

504
AO, Lyons M, Collins P, Nevill A. A cross-cultural comparison of health behaviors between Saudi and British adolescents living in urban areas: Gender by country analyses. Int J Environ Res Public Health. 2013; 10(12):6701-20.

55. Al-Nakeeb Y, Lyons M, Collins P, Al-Nuaim A, Al-Hazzaa H, Duncan MJ, Nevill A. Obesity, physical activity and sedentary behavior amongst British and Saudi youth: A cross-cultural study. Int J Environ Res Public Health. 2012; 9(4):1490-506.

56. Samara A, Aro AR, Alrammah T, Nistrup A. Lack of facilities rather than sociocultural factors as the primary barrier to physical activity among female Saudi university students. Int J Womens Health. 2015; 7:279.

57. Wills W, Backett-Milburn K, Gregory S, Lawton J. Young teenagers' perceptions of their own and others' bodies: A qualitative study of obese, overweight and "normal" weight young people in Scotland. Soc Sci Med. 2006; 62(2):396-406.

58. O'Dea JA. Gender, ethnicity, culture and social class influences on childhood obesity among Australian schoolchildren: Implications for treatment, prevention and community education. Heal Soc Care Community. 2008; 16(3):282-90.

59. Lawton J, Ahmad N, Hanna L, Douglas M, Hallowell N. "I can't do any serious exercise": Barriers to physical activity amongst people of Pakistani and Indian origin with type 2 diabetes. Health Educ Res. 2006; 21(1):43-54.

60. Modesti PA, Reboldi G, Cappuccio FP, Agyemang C, Remuzzi G, Rapi S, Perruolo E, Parati G, ESH Working Group on CV Risk in Low Resource Settings. Panethnic differences in blood pressure in Europe: A systematic review and meta-analysis. PLoS One. 2016; 11(1):e0147601.

61. Hedrick VE, Dietrich AM, Estabrooks PA, Savla J, Serrano E, Davy BM. Dietary biomarkers: Advances, limitations and future directions. Nutr J. 2012; 11(1):109.

62. Gosadi I, Alatar A, Otayf M, AlJahani D, Ghabbani H, AlRajban W, Alrsheed AM, AlNasser KA. Development of a Saudi Food Frequency Questionnaire and testing its reliability and validity. Saudi Med J. 2017; 38(6):636-41. 


\section{Table $\mathbf{1}$ (on next page)}

Table 1 Background information and characteristics of Gulf Cooperation Countries (GCC)

*PubMed; Web of Science; MEDLINE; DOAJ (Directory of Open Access Journals) 
1 Table 1 Background information and characteristics of Gulf Cooperation Countries (GCC)

$2(1)$.

\begin{tabular}{|c|c|c|c|c|c|c|}
\hline & Bahrain & Kuwait & Oman & Qatar & $\begin{array}{c}\text { Saudi } \\
\text { Arabia }\end{array}$ & UAE \\
\hline $\begin{array}{l}\text { Year country } \\
\text { was founded/ } \\
\text { independent }\end{array}$ & 1971 & 1961 & 1951 & 1971 & 1932 & 1971 \\
\hline $\begin{array}{l}\text { Surface area } \\
\left(\mathrm{km}^{2}\right)\end{array}$ & 774 & 17,188 & 309,500 & 11,628 & $2,149,690$ & 77,700 \\
\hline $\begin{array}{l}\text { Population } \\
\text { (thousands) in } \\
2016\end{array}$ & 1425 & 4053 & 4425 & 2570 & 32,276 & 9250 \\
\hline $\begin{array}{l}\text { Obesity } \\
\text { prevalence in } \\
2011(\%)\end{array}$ & 27.1 & 35.1 & 23.7 & 31.8 & 32.1 & 28.3 \\
\hline $\begin{array}{l}\text { Obesity } \\
\text { prevalence in } \\
2016(\%)\end{array}$ & 29.8 & 37.9 & 27 & 35.1 & 35.4 & 31.7 \\
\hline $\begin{array}{l}\text { Net change in } \\
\text { obesity }(\%)\end{array}$ & +2.7 & +2.8 & +3.3 & +3.3 & +3.3 & +3.4 \\
\hline $\begin{array}{l}\text { Total number } \\
\text { of hits using } \\
\text { keywords* }\end{array}$ & 29 & 64 & 56 & 52 & 176 & 46 \\
\hline $\begin{array}{l}\text { Studies } \\
\text { included }\end{array}$ & $\begin{array}{c}\mathbf{1} \\
\text { (Musaiger } \\
\text { et al., 2011) } \\
(32)\end{array}$ & $\begin{array}{c}1 \\
\text { (Al Baho } \\
\text { and Badr, } \\
\text { 2011) (40) }\end{array}$ & $\mathbf{0}$ & $\begin{array}{c}\mathbf{2} \\
\text { (Haj Bakri \& } \\
\text { Al-Thani, } \\
\text { 2012) (31) } \\
\\
\text { (Donnelly et } \\
\text { al., 2018) } \\
\text { (29) }\end{array}$ & $\begin{array}{c}\mathbf{3} \\
\text { (Moradi-Lakeh } \\
\text { et al., 2017) (30) } \\
\text { (Al-Hazzaa et } \\
\text { al., 2011) (34) } \\
\text { (AlBuhairan et } \\
\text { al., 2015) (38) }\end{array}$ & $\mathbf{0}$ \\
\hline
\end{tabular}

*PubMed; Web of Science; MEDLINE; DOAJ (Directory of Open Access Journals) 


\section{Table 2 (on next page)}

Table 2 Study characteristics of national dietary assessment studies conducted in Arab Gulf countries $(n=7)$.

*where possible, names of Arab food have been included

\# number

SSB: sugar sweetened beverages 
Table 2 Study characteristics of national dietary assessment studies conducted in Arab Gulf countries (n=7)

2

\begin{tabular}{|c|c|c|c|c|c|c|c|c|c|}
\hline \multirow[b]{2}{*}{ Author } & \multirow[b]{2}{*}{ Country } & \multirow[b]{2}{*}{$\begin{array}{l}\text { Age } \\
\text { range }\end{array}$} & \multirow[b]{2}{*}{$\begin{array}{l}\text { Sample } \\
\text { size }\end{array}$} & \multicolumn{5}{|c|}{ Tool(s) used } & \multirow[b]{2}{*}{ Findings } \\
\hline & & & & Type & $\begin{array}{l}\# \text { of } \\
\text { total } \\
\text { food } \\
\text { items }\end{array}$ & $\begin{array}{l}\text { \# and type } \\
\text { of Arab } \\
\text { food* }\end{array}$ & Measurement & Validated & \\
\hline $\begin{array}{l}\text { Al Baho \& } \\
\text { Badr, } \\
2011(40)\end{array}$ & Kuwait & $13-15$ & $\begin{array}{l}2674 \\
(1399 \text { male; } \\
1275 \\
\text { female) }\end{array}$ & $\begin{array}{l}\text { FFQ } \\
(2011 \\
\text { Kuwait } \\
\text { GSHS) }\end{array}$ & $\begin{array}{l}6 \\
\text { (includes } \\
\text { breakfast } \\
\text { meal) }\end{array}$ & $\begin{array}{l}2 \\
\text { Coriander } \\
\text { (vegetable); } \\
K D D, \\
\text { KDcow, } \\
\text { Carnation } \\
\text { (dairy) }\end{array}$ & $\begin{array}{l}\text { times/day in } \\
\text { past } 30 \text { days } \\
\text { (except } \\
\text { breakfast: } \\
\text { how often in } \\
\text { last } 30 \text { days: } \\
\text { Never, Rarely, } \\
\text { Sometimes, } \\
\text { Mostly, } \\
\text { Always) }\end{array}$ & $\begin{array}{l}\text { Not } \\
\text { validated }\end{array}$ & $\begin{array}{l}\text { Over } 30 \text { days, } 36 \% \\
\text { of students usually } \\
\text { ate fruits ( } \geq 2 \\
\text { times/day); } \\
19 \% \text { ate vegetables } \\
\text { ( } \geq 3 \text { times/day); } \\
75 \% \text { consumed } \\
\text { soft drink ( } \geq 1 \\
\text { times/day); } 36 \% \\
\text { drank milk ( } \leq 2 \\
\text { times /day); } 48 \% \\
\text { had fast food ( } \geq 3 \\
\text { times/week). }\end{array}$ \\
\hline $\begin{array}{l}\text { AlBuhairan } \\
\text { et al., } \\
\text { 2015(38) }\end{array}$ & $\begin{array}{l}\text { Saudi } \\
\text { Arabia }\end{array}$ & $12-19$ & $\begin{array}{l}12575 \\
(6444 \text { male; } \\
6131 \\
\text { female) }\end{array}$ & $\begin{array}{l}\text { FFQ } \\
\text { (Global } \\
\text { School- } \\
\text { based } \\
\text { Student } \\
\text { Health } \\
\text { Survey) }\end{array}$ & $\begin{array}{l}8 \\
\text { (includes } \\
\text { meals) }\end{array}$ & $\begin{array}{l}2 \\
\text { Fatayer } \\
\text { (snack); } \\
\text { molokhiya } \\
\text { (vegetable) }\end{array}$ & $\begin{array}{l}\text { srvgs/day } \\
\text { breakfast: last } \\
30 \text { days } \\
\text { (never, rarely, } \\
\text { some, most, } \\
\text { daily) } \\
\text { Number of } \\
\text { main meals }\end{array}$ & $\begin{array}{l}\text { Not } \\
\text { validated }\end{array}$ & $\begin{array}{l}38 \% \text { of } \\
\text { adolescents ate } \geq 1 \\
\text { srvgs/day of fruit } \\
\text { and } 54.3 \% \text { ate } \geq 1 \\
\text { srvgs/day of } \\
\text { vegetables. } 38 \% \\
\text { drank } \geq 2 \\
\text { carbonated } \\
\text { beverages/day. }\end{array}$ \\
\hline
\end{tabular}


per day? (0 -

$>4$ )

\begin{tabular}{|c|c|c|c|c|c|c|c|c|c|}
\hline $\begin{array}{l}\text { Al-Hazzaa } \\
\text { et al., } \\
2011(34)\end{array}$ & $\begin{array}{l}\text { Saudi } \\
\text { Arabia }\end{array}$ & $14-19$ & $\begin{array}{l}2908 \\
(1401 \text { male; } \\
1507 \\
\text { female) }\end{array}$ & $\begin{array}{l}\text { FFQ } \\
\text { (Arab } \\
\text { Teen } \\
\text { Lifestyle } \\
\text { Survey } \\
\text { (ATLS)) }\end{array}$ & $\begin{array}{l}9 \\
\text { (includes } \\
\text { meals) }\end{array}$ & None & days/wk & $\begin{array}{l}\text { Not } \\
\text { validated for } \\
\text { dietary } \\
\text { questions }\end{array}$ & $\begin{array}{l}\text { In Saudi } \\
\text { adolescents, an } \\
\text { average of } 22.8 \% \\
\text { consumed } \\
\text { vegetables daily; } \\
12.8 \% \text { had fruit } \\
\text { daily; } 29.15 \% \text { had } \\
\text { milk daily; } 62.35 \% \\
\text { consumed sugar- } \\
\text { sweetened } \\
\text { beverages (SSB) } \\
\text { (>3 day/week); } \\
27.55 \% \text { fast food } \\
\text { (>3 day/week); } \\
27.85 \% \text { french } \\
\text { fries/potato chips } \\
\text { (>3 day/week); } \\
26.8 \% \\
\text { cake/donut/biscuit } \\
\text { intake (>3 } \\
\text { day/week); } \\
44.95 \% \\
\text { sweets/chocolates } \\
\text { intake ( }>3 \\
\text { day/week); } \\
50.65 \% \text { energy } \\
\text { drinks intake ( }>3\end{array}$ \\
\hline
\end{tabular}




\begin{tabular}{|c|c|c|c|c|c|c|c|c|c|}
\hline $\begin{array}{l}\text { Donnelly } \\
\text { et al., } 2018 \\
(29)\end{array}$ & Qatar & $\geq 18$ & $\begin{array}{l}1606 \\
\text { (804 male; } \\
802 \text { female) }\end{array}$ & FFQ & 20 & $\begin{array}{l}1 \\
\text { Shawarma } \\
\text { (meat } \\
\text { products) }\end{array}$ & $\begin{array}{l}\text { Never, } \\
\text { Seldom, } \\
\text { times/wk, } \\
\text { once or more } \\
\text { daily }\end{array}$ & Validated & $\begin{array}{l}\text { Participants ate fruits } \\
(35.8 \%) \text {, green } \\
\text { vegetables }(31.8 \%) \\
\text { and other vegetables } \\
(44.1 \%) \text { at least once } \\
\text { daily. } 44.7 \% \\
\text { consumed milk } \\
\text { products and } 14.4 \% \\
\text { drank carbonated } \\
\text { soda more than once } \\
\text { daily. } 26.1 \% \text { of } \\
\text { participants on } \\
\text { average ate pasta, } \\
\text { snacks and cakes or } \\
\text { pastries } 2-4 \\
\text { times/week. An } \\
\text { average of } 32 \% \\
\text { consumed protein } \\
\text { products } 2-4 \\
\text { times/week. }\end{array}$ \\
\hline $\begin{array}{l}\text { Haj Bakri } \\
\& \\
\text { Al-Thani, } \\
\text { 2012(31) }\end{array}$ & Qatar & $18-64$ & $\begin{array}{l}2496 \\
(1053 \text { male; } \\
1443 \\
\text { female) }\end{array}$ & $\begin{array}{l}\text { FFQ via } \\
\text { face-to- } \\
\text { face } \\
\text { interviews } \\
\text { STEPS } \\
\text { Instrument } \\
\text { (WHO } \\
\text { 2005) } \\
\text { adapted } \\
\text { for Qatar- }\end{array}$ & 2 & None & $\begin{array}{l}\text { days/wk } \\
\text { AND } \\
\text { srvgs/day }\end{array}$ & $\begin{array}{l}\text { Not } \\
\text { validated }\end{array}$ & $\begin{array}{l}91 \% \text { of the Qatari } \\
\text { studied population } \\
\text { consumes }<5 \\
\text { srvgs/day of fruits } \\
\text { and/or vegetables. } \\
\text { Average number } \\
\text { of fruit servings } \\
\text { was } 0.8 \text { srvgs/day. } \\
\text { Average number } \\
\text { of vegetable }\end{array}$ \\
\hline
\end{tabular}




\begin{tabular}{|c|c|c|c|c|c|c|c|c|c|}
\hline & & & & $\begin{array}{l}\text { specific } \\
\text { context) }\end{array}$ & & & & & $\begin{array}{l}\text { servings was } 1.4 \\
\text { srvgs/day. Overall } \\
\text { average combined } \\
\text { fruit and/or } \\
\text { vegetable servings } \\
\text { was } 2.2 \text { srvgs/day. }\end{array}$ \\
\hline $\begin{array}{l}\text { Moradi- } \\
\text { Lakeh et } \\
\text { al., } \\
2017(30)\end{array}$ & $\begin{array}{l}\text { Saudi } \\
\text { Arabia }\end{array}$ & $15-60+$ & $\begin{array}{l}10735 \\
(5253 \text { male; } \\
5482 \\
\text { female })\end{array}$ & $\begin{array}{l}\text { FFQ via } \\
\text { interview; } \\
\text { pictures of } \\
\text { serving } \\
\text { sizes }\end{array}$ & 14 & $\begin{array}{l}2 \\
\text { Laban and } \\
\text { labneh } \\
\text { (yogurt } \\
\text { products) }\end{array}$ & $\begin{array}{l}\text { days/wk in the } \\
\text { last year } \\
\text { AND } \\
\text { g/day or } \\
\text { ml/day }\end{array}$ & $\begin{array}{l}\text { Not } \\
\text { validated }\end{array}$ & $\begin{array}{l}11 \% \text { of subjects } \\
\text { ate fruits daily and } \\
26 \% \text { ate vegetables } \\
\text { daily. } \\
27 \% \text { drank SSB } \\
\text { daily. } \\
\text { Dietary guideline } \\
\text { recommendations } \\
\text { for fruits were met } \\
\text { by only } 5.2 \% \text { of } \\
\text { participants and } \\
7.5 \% \text { for } \\
\text { vegetables. } \\
85 \% \text { met the } \\
\text { recommended } \\
\text { intake for meat and } \\
80 \% \text { met } \\
\text { recommendations } \\
\text { for processed } \\
\text { meats. }\end{array}$ \\
\hline $\begin{array}{l}\text { Musaiger } \\
\text { et al., } \\
2011(32)\end{array}$ & Bahrain & $15-18$ & $\begin{array}{l}735 \\
\text { subjects } \\
\text { (339 male; } \\
396 \text { female) }\end{array}$ & FFQ & $\begin{array}{l}18 \\
\text { (includes } \\
\text { meals) }\end{array}$ & None & $\begin{array}{l}\text { times/wk } \\
\text { fast food/soft } \\
\text { drinks: }\end{array}$ & $\begin{array}{l}\text { Modified } \\
\text { from } \\
\text { validated } \\
\text { questionnaire }\end{array}$ & $\begin{array}{l}\text { Approximately } \\
25 \% \text { of } \\
\text { respondents } \\
\text { reported eating }\end{array}$ \\
\hline
\end{tabular}




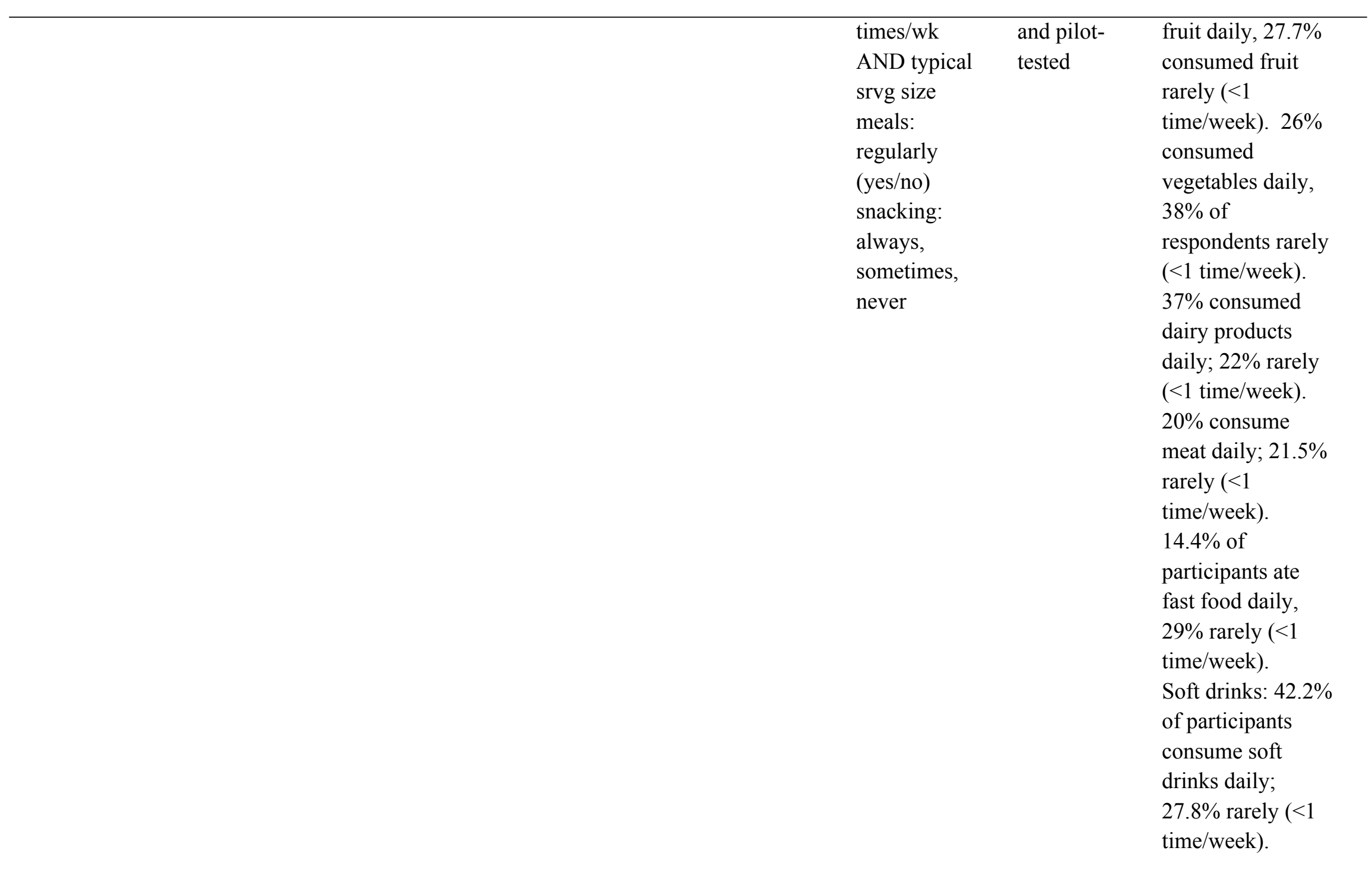




\section{Table 3 (on next page)}

Table 3 Quality assessment of national dietary assessment studies conducted in GCC countries using a scoring system $(n=7)$. 
1 Table 3 Quality assessment of national dietary assessment studies conducted in GCC countries using a scoring system (n=7).

\begin{tabular}{|c|c|c|c|c|c|c|c|c|c|}
\hline \multirow[b]{2}{*}{ Author } & \multirow[b]{2}{*}{ Design } & \multicolumn{5}{|c|}{ Selection } & \multicolumn{2}{|c|}{ Outcome } & \multirow{2}{*}{$\begin{array}{l}\text { Total } \\
\text { Score } \\
\text { (out } \\
\text { of } 12 \text { ) }\end{array}$} \\
\hline & & $\begin{array}{l}\text { Representative } \\
\text { of sample }\end{array}$ & $\begin{array}{l}\text { Sample } \\
\text { size }\end{array}$ & $\begin{array}{l}\text { Non- } \\
\text { respondents }\end{array}$ & $\begin{array}{l}\text { Ascertainment } \\
\text { of exposure } \\
\text { (validated) }\end{array}$ & Adaptability & $\begin{array}{l}\text { Assessment } \\
\text { of outcome }\end{array}$ & $\begin{array}{l}\text { Statistical } \\
\text { test }\end{array}$ & \\
\hline $\begin{array}{l}\text { Al Baho \& } \\
\text { Badr, 2011(40) }\end{array}$ & $\begin{array}{l}\text { cross- } \\
\text { sectional }\end{array}$ & + & + & + & + & + & ++ & + & 8 \\
\hline $\begin{array}{l}\text { AlBuhairan } \\
\text { et al., 2015(38) }\end{array}$ & $\begin{array}{l}\text { cross- } \\
\text { sectional }\end{array}$ & + & + & + & + & + & ++ & + & 8 \\
\hline $\begin{array}{l}\text { Al-Hazzaa } \\
\text { et al., 2011(34) }\end{array}$ & $\begin{array}{l}\text { cross- } \\
\text { sectional }\end{array}$ & + & + & & + & & ++ & + & 6 \\
\hline $\begin{array}{l}\text { Donnelly et } \\
\text { al., 2018(29) }\end{array}$ & $\begin{array}{l}\text { cross- } \\
\text { sectional }\end{array}$ & + & + & & +++ & + & ++ & + & 9 \\
\hline $\begin{array}{l}\text { Haj Bakri \& } \\
\text { Al-Thani, } \\
\text { 2012(31) }\end{array}$ & $\begin{array}{l}\text { cross- } \\
\text { sectional }\end{array}$ & + & + & + & + & & +++ & + & 8 \\
\hline $\begin{array}{l}\text { Moradi-Lakeh } \\
\text { et al., 2017(30) }\end{array}$ & $\begin{array}{l}\text { cross- } \\
\text { sectional }\end{array}$ & + & + & + & + & + & +++ & + & 9 \\
\hline $\begin{array}{l}\text { Musaiger } \\
\text { et al., 2011(32) }\end{array}$ & $\begin{array}{l}\text { cross- } \\
\text { sectional }\end{array}$ & + & + & + & ++ & & +++ & + & 9 \\
\hline
\end{tabular}




\section{PeerJ}


Figure 1

Figure 1 Flow chart of study eligibility of dietary studies conducted in GCC countries.

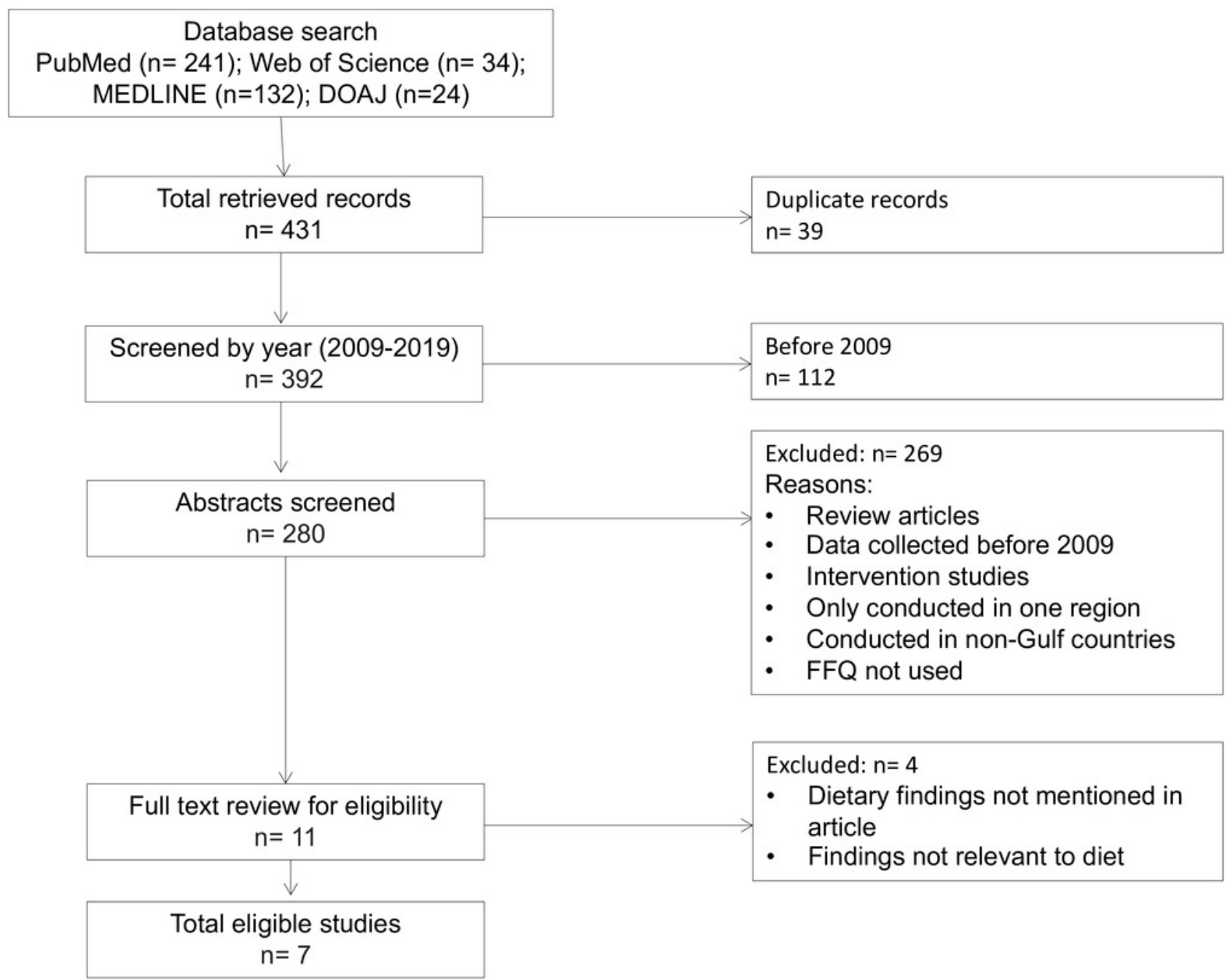

